\title{
The Effectiveness of Whatsapp-Based Online Learning in Class Students IV SD Negeri Babakandesa
}

\author{
Ejen Jenal Mutaqin ${ }^{1}$, Neni Nadiroti Muslihah ${ }^{2}$, Nizar Alam Hamdani ${ }^{3}$, Sifa \\ Nurfalah $^{4}$
}

1,2,4 Institut Pendidikan Indonesia

3Universitas Garut

jenalmutaqin@institutpendidikan.ac.id

\section{Article History}

accepted 05/11/2020

approved 10/11/2020

published 01/02/2021

\begin{abstract}
This research uses a descriptive qualitative approach with teacher and grade IV student research subjects. The data collection techniques used are questionnaires, interviews, and documentation. Based on the results of research conducted the effectiveness of online learning based on whatsapp is seen from 4 aspects with the results of presentase calculations showing that the quality of learning (39\%) with weak criteria, learning level (38\%) with weak, intensive criteria (48\%) with sufficient criteria and time (58\%) with sufficient criteria. Overall whatsappbased online learning conducted in Babakandesa State Elementary School is considered less effective. Seen from the many problems that occur in the online learning process, including the limitations of internet quota, less stable internet network and difficulty in understanding the material provided by teachers through whatsapp application.
\end{abstract}

Keywords: effectiveness of learning, online, whatsapp

\begin{abstract}
Abstrak
Penelitian ini bertujuan untuk mendeskripsikan bagaimana efektivitas pembelajaran daring berbasis whatsapp pada siswa kelas IV SD Negeri Babakandesa dan kendala yang dialami dalam proses pembelajaran daring berbasis whatsapp pada siswa kelas IV SD Negeri Babakandesa. Penelitian ini menggunakan pendekatan kualitatif deskriptif dengan subjek penelitian guru dan siswa kelas IV. Adapun teknik pengumpulan data yang digunakan yaitu angket, wawancara, dan dokumentasi. Berdasarkan hasil penelitian yang dilakukan keefektifan pembelajaran daring berbasis whatsapp dilihat dari 4 aspek dengan hasil perhitungan presentase menunjukkan bahwa kualitas pembelajaran $(39 \%)$ dengan kriteria lemah, tingkat pembelajaran (38\%) dengan kriteria lemah, intensif (48\%) dengan kriteria cukup serta waktu $(58 \%)$ dengan kriteria cukup. Secara keseluruhan pembelajaran daring berbasis whatsapp yang dilakukan di SD Negeri Babakandesa dinilai masih kurang efektif. Terlihat dari masih banyaknya permasalahan yang terjadi dalam proses pembelajarannya seperti adanya keterbatasan kuota internet, jaringan internet yang kurang stabil serta kesulitan siswa dalam memahami materi yang diberikan oleh guru melalui aplikasi whatsapp.
\end{abstract}

Kata kunci: efektivitas pembelajaran, daring, whatsapp

Social, Humanities, and Education Studies (SHEs): Conference Series https://jurnal.uns.ac.id/shes

p-ISSN 2620-9284

e-ISSN 2620-9292 


\section{PENDAHULUAN}

Seluruh negara di dunia tengah dilanda wabah penyakit yang disebabkan oleh virus yang bernama coronavirus disease atau lebih dikenal dengan istilah COVID-19. Virus ini menjadi salah satu persoalan multidimensi yang dihadapi dunia, hal tersebut juga dirasakan dampaknya dalam sektor pendidikan yang menyebabkan penurunan kualitas belajar pada peserta didik (Sahu, 2020). Menteri Pendidikan dan Kebudayaan (Mendikbud) menindak lanjuti kebijakan pemerintah dengan meliburkan sekolah dan mengganti proses Kegiatan Belajar Mengajar (KBM) dengan menggunakan sistem dalam jaringan (daring). Hal ini berdasarkan Surat Edaran (SE) No. 4 Tahun 2020 Tentang Pelaksanaan Kebijakan Pendidikan dalam Masa Darurat COVID-19. Masa darurat pandemi ini mengharuskan sistem pembelajaran diganti dengan pembelajaran daring agar proses pembelajaran tetap berlangsung (Sintema, 2020).

Penghentian pembelajaran secara tatap muka langsung bukan berarti Kegiatan Belajar Mengajar (KBM) menjadi berhenti, pembelajaran harus tetap dilakukan walaupun di rumah secara daring dengan memanfaatkan teknologi dan media internet yang ada. Hal ini sejalan dengan pendapat Wijaya (Suryawan, 2020) yang menyatakan bahwa belajar di rumah tidak menjadi masalah karena pembelajaran bisa dilakukan kapan dan dimana saja, apalagi sudah didukung dengan sistem daring. Salah satunya dengan memanfaatkan aplikasi internet yang tersedia seperti whatsapp. Menurut Pranajaya dan Wicaksono (Raharti, 2019, hlm. 148) menyebutkan bahwa whatsapp merupakan media sosial paling populer yang dapat digunakan sebagai media komunikasi. Umumnya para pengguna whatsapp menyebutkan alasan memilih aplikasi ini adalah karena tersedianya berbagai kemudahan yang ada didalamnya disamping tidak mengeluarkan biaya atau gratis.

Melalui penerapan kebijakan pembelajaran jarak jauh atau pembelajaran daring ini, diharapkan dunia pendidikan turut serta mendukung pemerintah dalam menekan laju penyebaran COVID-19. SD Negeri Babakandesa merupakan salah satu sekolah yang merespon kebijakan pemerintah dengan penerapan pembelajaran secara daring dan bekerja dari rumah sejak dikeluarkannya Surat Edaran dari Bupati Sumedang Nomor 443/2016/Um tanggal 27 Maret 2020 tentang optimalisasi penyebaran COVID19 pada Satuan Pendidikan. Banyak sekolah, termasuk SD Negeri Babakandesa yang belum terbiasa melakukan pembelajaran secara daring sehingga memunculkan berbagai masalah yang dihadapi oleh guru maupun peserta didik.

Berdasarkan wawancara dengan guru kelas IV SD Negeri Babakandesa terdapat beberapa kendala dalam proses pembelajaran daring diantaranya sebagian siswa tidak memiliki fasilitas internet yang memadai dalam menunjang proses pembelajaran daring, kemudian peserta didik juga lebih susah memahami materi yang diberikan guru karena kurangnya interaksi antara guru dengan peserta didik, sehingga hal ini menuntut kreativitas guru untuk mengembangkan pembelajarannya, baik dalam hal metode maupun media yang digunakan dalam proses pembelajaran daring.

Hamalik (Rohmawati, 2015, hlm. 16) menyatakan bahwa pembelajaran yang efektif adalah pembelajaran yang menyediakan kesempatan belajar sendiri atau melakukan aktivitas seluas-luasnya kepada siswa untuk belajar. Menurut Slavin (Triwibowo, 2015) ada empat indikator yang dapat kita gunakan untuk mengukur efektivitas suatu pembelajaran yaitu: (a) Mutu pengajaran, (b) Tingkat Pembelajaran yang tepat (c) Intensif dan (d) Waktu.

Selanjutnya Sanjaya (2014, hlm. 205) mengemukakan pembelajaran online adalah pembelajaran yang dilakukan dengan mengandalkan pada sumber-sumber informasi yang tersedia pada jaringan internet. Dari konsep ini maka jelas pembelajaran online erat kaitannya dengan pemanfaatan internet, sebagai sumber belajar. Menurut Bilfaqih dan Qomarudin (2015, hlm. 4) secara umum, pembelajaran daring bertujuan untuk memberikan layanan pembelajaran bermutu secara dalam 
jaringan (daring) yang bersifat massif dan terbuka untuk menjangkau audiens yang lebih banyak dan luas.

Penggunaan media dalam pembelajaran online dapat dijadikan alternatif dalam menunjang pembelajaran daring agar peserta didik mampu memahami materi pelajaran dengan baik. Salah satunya dengan memanfaatkan aplikasi internet yang tersedia seperti whatsapp. Menurut Pranajaya dan Wicaksono (Raharti, 2019, hlm. 148) menyebutkan bahwa whatsapp merupakan media sosial paling populer yang dapat digunakan sebagai media komunikasi. Umumnya para pengguna whatsapp menyebutkan alasan memilih aplikasi ini adalah karena tersedianya berbagai kemudahan yang ada didalamnya disamping tidak mengeluarkan biaya atau gratis.

Adapun berdasarkan hal demikian, maka peneliti merumuskan masalah sebagai berikut: (1). Bagaimana efektivitas pembelajaran daring berbasis whatsapp pada siswa kelas IV SD Negeri Babakandesa?, dan (2) Apa saja kendala dari proses pembelajaran daring berbasis whatsapp pada siswa Kelas IV di SD Negeri Babakandesa? Sehingga tujuan dalam melakukan penelitian ini adalah untuk mengetahui efektivitas dan proses pembelajaran daring berbasis whatsapp pada siswa kelas IV SD Negeri Babakandesa.

\section{METODE}

Metode yang digunakan dalam penelitian ini adalah metode penelitian deskriptif kualitatif, dengan melibatkan beberapa partisipan yaitu 20 siswa kelas IV SD Negeri Babakandesa dan 1 Guru kelas IV SD Negeri Babakandesa. Adapun teknik pengumpulan data yang digunakan dalam penelitian ini yaitu angket, wawancara dan dokumentasi. Analisis data yang digunakan dalam penelitian ini yaitu dengan teknik triangulasi data.

\section{HASIL DAN PEMBAHASAN \\ Efektivitas Pembelajaran Daring Berbasis Whatsapp}

Kualitas pembelajaran

Berdasarkan hasil penelitian yang telah dilakukan melalui angket secara keseluruhan presentase menunjukkan bahwa kualitas pembelajaran daring berbasis whatsapp yang dilakukan di kelas IV SD Negeri Babakandesa berkriteria lemah dengan memperoleh nilai rata-rata keseluruhan sebesar 39\% yang bermakna bahwa siswa berkategori lemah dalam melakasanakan proses pembelajaran daring berbasis whatsapp. Hasil angket tersebut berbeda dengan penelitian yang dilakukan oleh Sayarifudin (2020) yang menyebutkan bahwa mutu pemdidikan atau kualitas pendidikan dapat ditingkatkan melalui pembelajaran daring. Siswa akan lebih berkompeten dalam menguasai kompetensi secara mandiri serta sehingga pembelajaran aktif akan terbentuk.

Selain itu, melalui hasil wawancara kualitas pembelajaran dalam proses pembelajaran daring berbasis whatsapp yang dilakukan siswa di kelas IV SD Negeri Babakandesa dinilai berjalan kurang efektif karena pembelajaran hanya sebatas pemberian tugas yang dilakukan oleh guru, siswa hanya mengerjakan tugas berupa LKS setiap hari nya melalui aplikasi grup whatsapp. Melihat hal di atas, Slavin (Pransetyapri, 2018) bahwa seberapa besar kadar informasi yang disajikan sehingga siswa dengan mudah dapat mempelajarinya atau tingkat kesalahannya semakin kecil. Semakin kecil tingkat kesalahan yang dilakukan berarti semakin efektif pembelajaran.

\section{Tingkat Pengajaran}

Selanjutnya untuk melihat tingkat pengajaran dalam penelitian ini menggunakan angket secara keseluruhan presentase menunjukkan bahwa tingkat pengajaran dalam pembelajaran daring berbasis whatsapp yang dilakukan di kelas IV SD Negeri Babakandesa berkategori lemah dengan memperoleh nilai rata-rata keseluruhan 
sebesar $38 \%$ yang makna bahwa siswa berkategori lemah dalam melakasanakan proses pembelajaran daring berbasis whatsapp. Ditambahkan melalui hasil wawancara, tingkat pengajaran dalam pembelajaran daring berbasis whatsapp dinilai berjalan kurang efektif. Karena dalam pelaksanaanya masih terdapat beberapa kendala yaitu kurangnya interkasi yang dilakukan antara guru dengan siswa, dimana hanya ada beberapa siswa yang aktif menanyakan kepada guru melalui aplikasi whatsapp ketika kurang paham dengan materi yang diberikan. Kebanyakan siswa lebih memilih bertanya kepada orang tua, sehingga guru kesulitan melihat kemampuan siswa dalam memahami materi yang diberikan. Hal tersebut tentunya akan mempengaruhi tingkat efektivitas pembelajaran daring yang dilakukan karena efektivitas pembelajaran ditandai dengan keaktifan siswa dalam suatu pembelajaran karena semakin aktif siswa dalam pembelajaran maka semakin efektif pula suatu proses pembelajaran yang dilakukan. Oleh karenanya, Slavin (Pransetyapri, 2018) menyebutkan bahwa tingkat pengajaran yang tepat yaitu sejauh mana guru memastikan bahwa siswa sudah siap mempelajari suatu pelajaran baru, maksudnya kemampuan dan pengetahuan yang diperlukan untuk mempelajarinya tetapi belum memperoleh pelajaran tersebut.

\section{Intensif}

Kemudian untuk melihat tingkat intensif pada penelitian ini melalui penggunaan angket secara keseluruhan presentase menunjukkan bahwa indikator intensif dalam pembelajaran daring berbasis whatsapp yang dilakukan di kelas IV SD Negeri Babakandesa berkategori cukup dengan memperoleh nilai rata-rata keseluruhan sebesar $48 \%$ yang makna bahwa siswa berkategori cukup dalam melakasanakan proses pembelajaran daring berbasis whatsapp.

Namun berdasarkan hasil wawancara, dalam pelakasanaanya bahwa pembelajaran daring berbasis whatsapp yang dilakukan masih memiliki beberapa kekurangan dari tingkat pengajarannya yaitu pada penyampaian materi pembelajaran tidak dilakukan setiap hari melainkan hanya untuk beberapa meteri pelajaran saja yang mengakibatkan siswa terkadang merasa bosan belajar secara daring melalui aplikasi whatsapp karena hanya mengerjakan tugas setiap harinya.

Menurut Slavin (Pransetyapri, 2018) Intensif yaitu sejauh mana guru memastikan bahwa siswa termotivasi untuk mengerjakan tugas-tugas pelajaran dan untuk mempelajari bahan yang sedang disajikan. Intensif dilihat dari aktivitas guru dalam memberikan motivasi kepada siswa.

\section{Waktu}

Keefektifan pembelajaran dalam penelitian ini dilihat apabila siswa dapat menyelesaikan pembelajaran sesuai dengan waktu yang ditentukan. Berikut presentase efektivitas pembelajaran daring berbasis whatsapp pada siswa kelas IV SD Negeri Babakandesa dari aspek waktu yang digunakan. Hasil penelitian dengan menggunakan angket secara keseluruhan presentase menunjukkan bahwa waktu yang digunakan dalam pembelajaran daring berbasis whatsapp pada siswa kelas IV SD Negeri Babakandesa berkategori cukup dengan memperoleh nilai rata-rata keseluruhan sebesar 58\% yang makna bahwa indikator waktu berkategori cukup dalam proses pembelajaran daring berbasis whatsapp. Hal ini sesuai dengan karakteristik yang paling menonjol dari pembelajaran online adalah memberikan kemudahan dan fleksibilitas bagi guru dan siswa terutama untuk menentukan jadwal belajar online dengan tidak mementingkan waktu dan lokasi (Bower, 2015).

Berdasarkan hasil wawancara waktu yang digunakan dalam pembelajaran daring berbasis whatsapp pada kelas IV SD Negeri Babakandesa berbeda dengan pembelajaran tatap muka langsung yaitu sekitar 1 sampai 2 jam setiap harinya. Ada 
beberapa siswa yang tidak mengerjakan dan mengumpulkan tugas tepat waktu karena tidak memiliki kuota internet.

\section{Kendala dalam Proses pembelajaran Daring berbasis Whatsapp}

Pelaksanaan pembelajaran daring berbasis whatsapp yang dilakukan pada siswa kelas IV SD Negeri Babakandesa memiliki beberapa kendala salah satunya yang dirasakan oleh siswa yaitu adanya keterbatasan kuota internet yang dimiliki serta jaringan internet yang kurang memadai. Sehingga pembelajaran secara daring ini dirasa kurang efektif. Hal ini juga dijelaskan oleh Husamah (2014) bahwa jika jaringan kurang memadai, maka akan berpengaruh pada pembelajaran yang dilaksanakan, sehingga hal tersebut akan menjadi tidak efektif.

Kemudahan penggunaan aplikasi whatsapp bagi guru dan siswa pun akan terhambat jika jaringan di sekitar rumah siswa dan guru mengalami gangguan. Akibatnya materi pembelajaran yang diberikan oleh guru juga menjadi terhambat dan terlambat. Selain itu penjelasan materi yang dilakukan tidak dilakukan oleh guru setiap hari melainkan hanya untuk beberapa materi pelajaran saja penjelasan materinya pun hanya berupa video pembelajaran yang diberikan melalui grup whatsapp. Sehingga pemahaman terhadap materi pelajaran menjadi salah satu kendala yang dialami siswa dalam proses pembelajaran daring melalui aplikasi whatsapp.

Selain itu, guru juga memaparkan mengenai kendala yang dialami oleh guru dalam proses pembelajaran daring berbasis whatsapp yaitu terletak pada saat penyampaian materi pembelajaran. Guru mengalami kesulitan dalam menyampaikan materi secara daring dikarenakan penerapan pembelajaran daring dilakukan secara tiba-tiba seiring dengan adanya virus corona ini yang menyebabkan baik siswa maupun guru belum terbiasa dan sepenuhnya mempersiapkan diri untuk melakukan kegiatan belajar secara online. Hal ini memaksa guru dan siswa untuk beralih menggunakan internet sebagai satu-satunya sarana yang memungkinkan untuk penyampaian materi pembelajaran.

Pemahaman terhadap materi pelajaran menjadi kendala yang dialami oleh siswa dalam proses pembelajaran daring melalui whatsapp. Perlu disadari bahwa ketidaksiapan guru dan siswa terhadap pembelajaran daring juga menjadi masalah. Perpindahan sistem belajar tatap muka langsung ke sistem daring amat mendadak tanpa persiapan yang matang. Tetapi semua ini harus tetap dilaksanakan agar proses pembelajaran dapat berjalan lancar dan siswa aktif mengikuti walaupun dalam kondisi pandemi ini.

\section{SIMPULAN}

Adapun kesimpulan dari penelitian ini adalah:

1. Efektivitas pembelajaran daring berbasis whatsapp pada siswa kelas IV SD Negeri Babakandesa dilihat dari 4 aspek. Pertama, dari kualitas pembelajaran berkategori lemah. Hal ini menunjukkan bahwa kualitas pembelajaran daring berbasis whatsapp yang dilakukan masih kurang efektif terlihat dari proses pembelajaran yang dilakukan baru sebatas pemberian tugas setiap harinya melalui grup whatsapp. Kedua, dari segi tingkat pembelajaran berkategori lemah. Hal ini menunjukkan bahwa tingkat pembelajaran daring yang dilaksanakan masih kurang efektif terlihat pada saat proses pembelajaran daring melalui whatsapp yang dilakukan, guru kesulitan untuk melihat kemampuan siswa. Ketiga, dari segi intensif berkategori cukup. Namun dalam pelaksanaannya dalam penyampaian materi pembelajaran oleh guru tidak dilakukan setiap hari, melainkan hanya untuk beberapa mata pelajaran saja. Sehingga siswa terkadang merasa bosan belajar secara daring melalui aplikasi whatsapp karena hanya mengerjakan tugas setiap harinya. Keempat, dari segi waktu yang digunakan dalam pembelajaran daring berkategori cukup. Dalam pelaksanaannya waktu yang digunakan berbeda dengan tatap muka 
secara langsung dimana guru lebih menyesuaikan dengan keadaan siswanya sehingga waktu yang digunakan lebih fleksibel.

2. Kendala dalam proses pembelajaran daring berbasis whatsapp pada siswa kelas IV SD Negeri Babakandesa diantaranya adanya keterbatasan kuota internet, jaringan internet yang kurang stabil serta kesulitan siswa dalam memahami materi yang diberikan oleh guru melalui aplikasi whatsapp.

\section{DAFTAR PUSTAKA}

Bower, M., Dalgarno, B., Kennedy, G. E., Lee, M. J., \& Kenney, J. (2015). Design and implementation factors in blended synchronous learning environments: Outcomes from a cross-case analysis. Computers \& Education, 8(6).

Shodiq, I. J. F., \& Zainiyati, H. S. (2020). Pemanfaatan Media Pembelajaran ELearning Menggunakan Whatsapp Sebagai Solusi ditengah Penyebaran COVID-19 di MI Nurulhuda Jelu. Al-Insyiroh: Jurnal Studi Keislaman, 6(2), 144-159.

Raharti. 2019. "Whatsapp” Media Komunikasi Efektif Masa Kini (Studi Kasus Pada Layanan Jasa Informasi IImiah Di Kawasan Puspiptek. Jurnal: Visi Pustaka. Vol. 21 (2): 148-151.

Rohmawati, A. (2015). Efektivitas Pembelajaran. Jurnal Pendidikan Usia Dini, 9(1), 1532.

Rusni, A., \& Lubis, E. E. (2017). Penggunaan Media Online Whatsapp Dalam Aktivitas Komunitas One Day One Juz (Odoj) Dalam Meningkatkan Minat Tilawah Odojer Di Kota Pekanbaru (Doctoral dissertation, Riau University).

Sanjaya, W. (2012). Media Komunikasi Pembelajaran. Jakarta: Kencana Prenadamedia Grup.

Sugiyono. (2018). Metode Penelitian, Kuantitatif, Kualitatif dan R\&D. Bandung: Alfabeta.

Sahu, P. (2020) Closure Of Universities Due Tp Coronavirus Disisese 2019 (COVID19) Impact on Educations and Mental Health of Students and academic staff.

Sintema, E. J. (2020) Effect of COVID-19 on the Performance of Grade 12 Student: Implications for STEM Education. Eurasia Journal of Mathematics, Science and Technology Education, 16(7), 1-6.

Suryawan, O. (2020). Guru Diminta Aktif Awasi Pembelajaran Daring Agar Siswa Tetap Fokus.bbalipuspanews.com

Triwibowo. (2015). Deskripsi Efektivitas Discovery Learning pada Pembelajaran Matematika di SMP Muhammadiyah 5 Purbalingga dan SMP Negeri 2 Rembang, Jurnal Pendidikan Matematika. 8(6), hlm. 7-10. 